\title{
Od badania ADVANCE do badania ADVANCE-ON - wpływ na rokowanie u pacjentów z nadciśnieniem i cukrzycą typu 2
}

\author{
From ADVANCE study to ADVANCE-ON study - the impact on prognosis \\ in patients with hypertension and type 2 diabetes
}

\author{
Beata Wożakowska-Kapłon ${ }^{1,2}$, Iwona Gorczyca-Michta ${ }^{1}$ \\ ${ }^{1}$ I Klinika Kardiologii i Elektroterapii Świętokrzyskiego Centrum Kardiologii w Kielcach \\ ${ }^{2}$ Wydział Nauk o Zdrowiu Uniwersytetu Jana Kochanowskiego w Kielcach
}

\section{Streszczenie}

W obecnych danych epidemiologicznych podkreśla się bieżące problemy związane z obniżeniem ciśnienia tętniczego u chorych na cukrzycę. W aktualnych wytycznych Europejskiego Towarzystwa Nadciśnienia Tętniczego i Europejskiego Towarzystwa Kardiologicznego zalecono rozważenie leczenia złożonego, najlepiej za pomocą ustalonych dawek, oraz leczenia zawierającego inhibitory układu renina-angiotensyna-aldosteron w celu ochrony przed nefropatią cukrzycową. Połączenie perindoprilu z diuretykiem tizydopodobnym - indapamidem jest jednym z najlepiej przebadanych w wieloośrodkowych badaniach klinicznych połączeniem.

Słowa kluczowe: lek złożony, perindopril, indapamid

(Folia Cardiologica 2015; 10, 2: 114-121)

\section{Wstęp}

Liczba chorych na nadciśnienie tętnicze się zwiększa i jest prognozowany jej dalszy wzrost. W 2000 roku liczba chorych na nadciśnienie tętnicze na świecie wynosiła 972 mln; do 2025 roku szacuje się niemal jej podwojenie [1]. Podobna tendencja dotyczy populacji polskiej. W Polsce nadciśnienie tętnicze stwierdza się u 10,5 mln osób, a do 2025 roku liczba takich chorych wzrośnie do $14 \mathrm{mln}$ [2]. Równie niepokojący, co wzrost liczby osób chorujących na nadciśnienie tętnicze, jest fakt złej kontroli ciśnienia tętniczego u większości pacjentów. Bardzo niską, jedynie 12-procentową, skuteczność leczenia nadciśnienia tętniczego wykazano w badaniu NATPOL w 2002 roku [3]. Według wyników badania NATPOL 2011 odsetek chorych ze skutecznie leczonym nadciśnieniem tętniczym zwiększył się 2-krotnie i obecnie wynosi 26\% [4]. Przeprowadzona przez NHANES (National Health and Nutrition Examination
Survey) analiza wykazała, że docelowe wartości ciśnienia tętniczego osiągnięto u 53\% osób leczonych z powodu nadciśnienia [5]. Niższy odsetek chorych skutecznie leczonych hipotensyjnie, wynoszący 48\%, stwierdzono we Framingham Heart Study [6]. Odsetek chorych osiągających docelowe wartości ciśnienia tętniczego w Stanach Zjednoczonych - choć nadal niski - osiąga zdecydowanie wyższą wartość niż w naszym kraju. Działania prozdrowotne, w tym także monitorowanie kontroli czynników ryzyka sercowo-naczyniowego, w Stanach Zjednoczonych rozpoczęto 20 lat wcześniej niż w Polsce.

\section{Leki złożone a skuteczna terapia nadciśnienia tętniczego}

Bramlage i wsp. [7] w badaniu obejmującym 18652 chorych leczonych z powodu nadciśnienia tętniczego wykazali, że u 31,2\% badanych zastosowano monoterapię, zaś

Adres do korespondencji: prof. dr hab. n. med. Beata Wożakowska-Kapłon, I Klinika Kardiologii i Elektroterapii, Świętokrzyskie Centrum Kardiologii, ul. Grunwaldzka 45, 25-736 Kielce, e-mail: bw.kaplon@poczta.onet.pl 


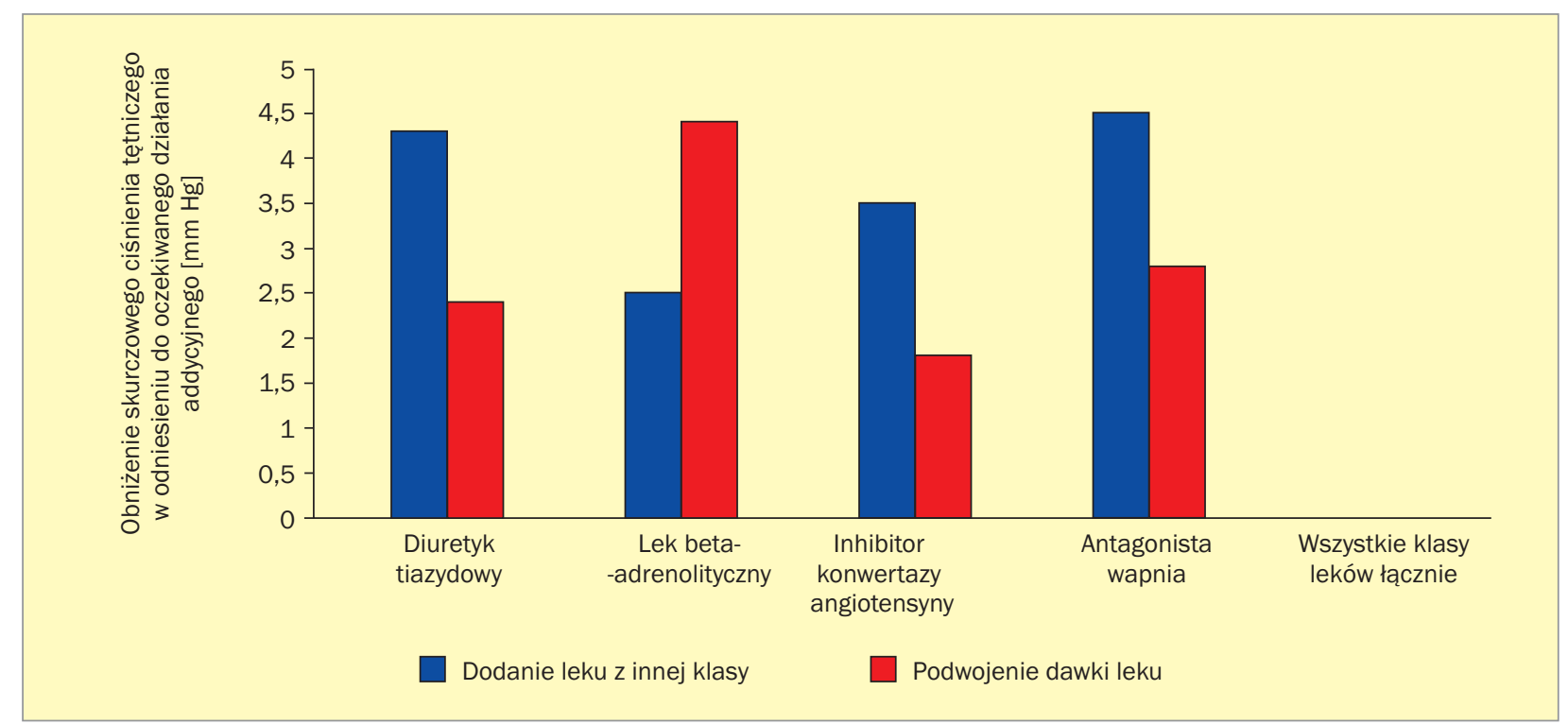

Rycina 1. Obniżenie skurczowego ciśnienia tętniczego u chorych leczonych podwojoną dawką leku lub dwoma lekami z różnych grup (opracowano na podstawie [11])

u pozostałych chorych prowadzono leczenie skojarzone. Docelowe wartości ciśnienia tętniczego osiągnięto jedynie u 21,2\% chorych. Najwyższy odsetek skutecznie leczonych pacjentów w tej obserwacji odnotowano w Ameryce Łacińskiej $(30,6 \%)$, a najniższy - na Bliskim Wschodzie $(9,6 \%)$ [7]. Dobrą kontrolę ciśnienia tętniczego częściej uzyskiwano u chorych bez cukrzycy niż u osób z tą chorobą $(25,3 \%$ v. $8,3 \%)[7]$.

Stosowanie leków złożonych znacznie poprawia skuteczność leczenia nadciśnienia tętniczego, głównie poprzez poprawę współpracy pacjenta z lekarzem. Uważa się, że w 50\% za nieskuteczność leczenia hipotensyjnego odpowiada niedostateczny stopień współpracy pacjenta z lekarzem [8]. Jest on uwarunkowany głównie dużą ilością przyjmowanych leków hipotensyjnych i skomplikowanymi schematami ich dawkowania. Gupta i wsp. [9] w metaanalizie obejmującej 15 badań i 32331 chorych dowiedli, że w grupie osób przyjmujących preparat złożony, w porównaniu z grupą pacjentów stosujących leki w osobnych tabletkach, stwierdzono lepsze przestrzeganie zasad stosowania leków (iloraz szans [OR, odds ratio] 1,21; 95-proc. przedział ufności [Cl, confidence interval] 1,03-1,43) oraz wyższą częstość wytrwania w zaleconej terapii (OR 1,54; $95 \% \mathrm{Cl}$ 0,95-2,49). W obu grupach obserwowano podobny stopień obniżenia skurczowego ciśnienia tętniczego (-4,1 mm Hg; od $-9,8$ do 1,5$)$ i rozkurczowego $(-3,1 \mathrm{~mm} \mathrm{Hg}$; od $-7,1$ do $0,9)$, a także podobną częstość osiągnięcia docelowych wartości ciśnienia tętniczego (OR 1,30; 95\% Cl 0,98-1,71). Działania niepożądane występowały z podobną częstością u chorych leczonych preparatem złożonym i u pacjentów otrzymujących kilka leków hipotensyjnych. Carrao i wsp. [10] wykazali, że zastosowanie skojarzonej terapii hipotensyjnej zamiast monoterapii obniża ryzyko przerwania leczenia o $73 \%$.
Korzyści wynikające ze stosowania leków hipotensyjnych z różnych grup wynikają ze skojarzenia różnych mechanizmów ich działania. Ponadto leczenie kilkoma preparatami w mniejszych dawkach obniża ryzyko wystąpienia działań niepożądanych w porównaniu ze zwiększaniem dawki jednego leku hipotensyjnego. W metaanalizie Walda i wsp. [11], obejmującej niemal 11 tys. chorych, udowodniono, że leczenie hipotensyjne dwoma lekami hipotensyjnymi z różnych grup jest 5-krotnie skuteczniejsze i bezpieczniejsze niż monoterapia podwojoną dawką jednego leku hipotensyjnego. Największą redukcję skurczowego ciśnienia tętniczego obserwowano u chorych wyjściowo otrzymujących inhibitor konwertazy angiotensyny, do którego dodawano lek hipotensyjny z innej grupy (ryc. 1) [11]. Egan i wsp. [12], w grupie 106621 chorych z niewyrównanym nadciśnieniem tętniczym, porównali strategię leczenia hipotensyjnego za pomocą monoterapii, terapii skojarzonej oraz terapii złożonej. W trwającej ponad rok obserwacji największą skuteczność hipotensyjną, tj. osiągnięcie docelowych wartości ciśnienia tętniczego u 68\% badanych, wykazano u chorych poddanych lekami hipotensyjnymi w jednej tabletce (terapia złożona). W grupie chorych leczonych kombinacją preparatów jednolekowych oraz w grupie chorych otrzymujących tylko jeden lek hipotensyjny nie stwierdzono różnic w zakresie skuteczności leczenia. W obu grupach docelowe wartości ciśnienia tętniczego osiągnięto u 59\% leczonych [12]. W analizie wieloczynnikowej wykazano, że stosowanie kilku substancji czynnych w jednej tabletce w porównaniu ze stosowaniem kilku leków hipotensyjnych osobno było najsilniejszym czynnikiem zwiększającym szansę na poprawę kontroli ciśnienia tętniczego (współczynnik ryzyka [HR, hazard ratio] 1,53, 95\% Cl 1,47-1,58) [12]. Zatem złożona terapia hipotensyjna, dzięki synergistycznemu wykorzystaniu mechanizmów działania leków z różnych grup, znacznie poprawia stopień kontroli nadciśnienia tętniczego. 


\section{Ogólne zasady leczenia nadciśnienia tętniczego u chorych na cukrzycę}

U chorych na cukrzycę nadciśnienie tętnicze występuje bardzo często, a częstość jego występowania zwiększa się z wiekiem, czasem trwania cukrzycy oraz współistnieniem powikłań makro- i mikroangiopatycznych [13]. Nadciśnienie tętnicze u osób z cukrzycą występuje 2 razy częściej niż w populacji ogólnej - dotyczy 10-30\% pacjentów z cukrzyca typu 1 i 60-80\% osób z cukrzycą typu 2 [13].

Ryzyko występowania uszkodzeń makro- i mikroangiopatycznych u chorych na cukrzyce jest wprost proporcjonalne do wartości ciśnienia tętniczego, co wykazano w jego całodobowym monitorowaniu [14]. Nadciśnienie tętnicze i cukrzyca są niezależnymi czynnikami ryzyka sercowo-naczyniowego, a - współistniejąc - działają synergistycznie, prowadząc do przyspieszonego rozwoju miażdżycy tętnic mózgowych, wieńcowych i obwodowych. Cukrzyca u chorych z nadciśnieniem tętniczym predysponuje do pogarszania się funkcji lewej komory, poprzez upośledzenie funkcji rozkurczowej mięśnia lewej komory oraz jego przerost [15]. Ponadto u chorych na cukrzyce dochodzi do wzmożenia sztywności naczyń [16]. Nadciśnienie tętnicze znacznie zwiększa też ryzyko wystąpienia powikłań mikroangiopatycznych u chorych na cukrzycę. U chorych ze współistniejącym nadciśnieniem tętniczym i cukrzycą istotnie wzrasta ryzyko wystąpienia nefropatii i schyłkowej niewydolności nerek.

Zalecane wartości docelowe ciśnienia tętniczego u chorych na cukrzycę są przedmiotem dyskusji. Uważa się, że u tych chorych należy stosować metody służące obniżeniu podwyższonego ciśnienia ze względu na fakt, że w tej grupie zwiększone ciśnienie tętnicze wiąże się z istotnym wzrostem ryzyka sercowo-naczyniowego. W randomizowanych badaniach przeprowadzonych u chorych na cukrzyce wykazano korzystny wpływ obniżania skurczowego ciśnienia tętniczego przynajmniej do wartości poniżej $140 \mathrm{~mm}$ Hg oraz rozkurczowego ciśnienia tętniczego do wartości mniejszej niż $85 \mathrm{~mm} \mathrm{Hg.}$

W UKPDS (United Kingdom Prospective Diabetes Study) dowiedziono, że w grupie chorych, u których osiągnięto niższe wartości ciśnienia tętniczego (średnia wartość 144/ /82 mm Hg) obserwowano zmniejszenie liczby zdarzeń makronaczyniowych o 24\% w porównaniu z osobami, u których średnie wartości ciśnienia tętniczego były wyższe (154/ /87 mm Hg) [17]. W badaniu Hypertension Optimal Treatment (HOT) stwierdzono zmniejszenie częstości występowania incydentów sercowo-naczyniowych, odpowiednio - 24,4/100, 18,6/100 oraz 11,9/100 pacjentów rocznie w odniesieniu do grup chorych z rozkurczowymi średnimi wartościami ciśnienia tętniczego $84 \mathrm{~mm} \mathrm{Hg}, 82 \mathrm{~mm} \mathrm{Hg}$ i $81 \mathrm{~mm} \mathrm{Hg}$ [18]. Natomiast w badaniu ACCORD (Action to control cardiovascular risk in diabetes) nie wykazano, by intensywne leczenie hipotensyjne (średnia wartość skurczowego ciśnienia tętniczego 119 mm Hg) wpływało na zmniejszenie częstości występowania złożonego punktu końcowego (zawał serca niezakończony zgonem, udar mózgu niezakończony zgonem lub zgon z przyczyn sercowo-naczyniowych) w porównaniu z chorymi leczonych mniej intensywnie [19]. Na kształt obecnie obowiązujących zaleceń dotyczących wartości docelowych ciśnienia tętniczego u chorych z cukrzycą, które zawarto w dokumencie European Society of Cardiology (ESC) poświęconym cukrzycy, stanu przedcukrzycowego i chorób układu sercowo-naczyniowego, opracowanych we współpracy z European Association for the Study of Diabetes (EASD) [20], wpłynęły wyniki analizy Bangalore [21]. W metaanalizie 13 badań obejmujących 37736 chorych z cukrzycą lub stanem przedcukrzycowym porównano pacjentów intensywnie leczonych hipotensyjnie (wartość skurczowego ciśnienia tętniczego $\leq 135 \mathrm{~mm} \mathrm{Hg}$ ) z grupą osób leczonych mniej intensywnie (wartość skurczowego ciśnienia tętniczego $\leq 140 \mathrm{~mm} \mathrm{Hg}$ ). Intensywniejsza kontrola hipotensyjna wiązała się ze zmniejszeniem śmiertelności całkowitej o 10\% i liczby udarów mózgu o 17\%. Wykazano także, że obniżanie skurczowego ciśnienia tętniczego do wartości $130 \mathrm{~mm}$ Hg lub niższej wiązało się z większą redukcją częstości udarów mózgu, jednak nie wpływało na inne zdarzenia sercowo-naczyniowe [21]. U chorych z cukrzycą i nadciśnieniem tętniczym należy zatem dążyć do osiągnięcia wartości ciśnienia tętniczego poniżej 140/ /85 mm Hg (klasa zaleceń I, poziom wiarygodności danych A) [20]. W celu osiągnięcia docelowych wartości ciśnienia tętniczego zaleca się terapię skojarzoną (klasa zaleceń I, poziom wiarygodności danych A) [20]. Ogólne zasady dotyczące leczenia hipotensyjnego u chorych na cukrzyce według zaleceń ESC i EASD z 2013 roku [20], które uzupełniają się z zaleceniami European Society of Hypertension (ESH) i ESC z 2013 roku [22], przedstawiono w tabeli 1.

\section{Leczenie skojarzone nadciśnienia tętniczego u chorych na cukrzycę}

Za stosowaniem zindywidualizowanej skojarzonej terapii hipotensyjnej (najlepiej złożonej) przemawia fakt, że u większości chorych z cukrzycą i nadciśnieniem tętniczym nie są osiągane wartości docelowe ciśnienia tętniczego. Analiza danych pochodzących z International Survey Evaluating Microalbuminuria Routinely by Cardiologists in patients with Hypertension (I-SEARCH) wykazała wśród chorych na cukrzycę dobrą kontrolę ciśnienia tętniczego u 19\% mężczyzn i u 16\% kobiet, mimo że 93,5\% pacjentów otrzymywało leki hipotensyjne [23]. Według wytycznych ESH i ESC z 2013 roku w terapii dwoma lekami hipotensyjnymi zaleca się wybór spośród następujących połączeń:

- inhibitor konwertazy angiotensyny + diuretyk tiazydowy;

- inhibitor konwertazy angiotensyny + antagonista wapnia;

- antagonista wapnia + diuretyk tiazydowy;

- sartan + diuretyk tiazydowy;

- sartan + antagonista wapnia (ryc. 2) [22]. 
Tabela 1. Zalecenia dotyczące leczenia nadciśnienia tętniczego u chorych na cukrzycę (źródła [20, 22])

\begin{tabular}{|c|c|c|}
\hline Zalecenie & Klasa zaleceń & Poziom wiarygodności danych \\
\hline $\begin{array}{l}\text { U osób z cukrzycą i nadciśnieniem tętniczym zaleca się kontrolę ciśnienia } \\
\text { tętniczego w celu obniżenia ryzyka zdarzeń sercowo-naczyniowych }\end{array}$ & I & A \\
\hline $\begin{array}{l}\text { Należy rozpoczynać farmakoterapię hipotensyjną u chorych na cukrzyce, } \\
\text { u których SBP } \geq 160 \mathrm{~mm} \mathrm{Hg} \text {, zdecydowanie zaleca się również rozpoczęcie } \\
\text { farmakoterapii w przypadku SBP } \geq 140 \mathrm{~mm} \mathrm{Hg}\end{array}$ & I & A \\
\hline $\begin{array}{l}\text { U osób z nadciśnieniem tętniczym i cukrzycą zaleca się indywidualny dobór } \\
\text { terapii z docelowymi wartościami ciśnienia tętniczego < 140/85 mm Hg }\end{array}$ & I & A \\
\hline $\begin{array}{l}\text { Zaleca się stosowanie terapii skojarzonej lekami hipotensyjnymi w celu } \\
\text { osiągnięcia odpowiedniej kontroli ciśnienia tętniczego }\end{array}$ & I & A \\
\hline $\begin{array}{l}\text { U chorych na cukrzyce mogą być zalecane i stosowane leki hipotensyjne } \\
\text { z wszystkich klas; można preferować inhibitory układu renina-angiotensyna- } \\
\text {-aldosteron, zwłaszcza w przypadku obecności białkomoczu } \\
\text { lub mikroalbuminurii }\end{array}$ & I & A \\
\hline $\begin{array}{l}\text { Zaleca się indywidualny dobór farmakoterapii z uwzględnieniem chorób } \\
\text { współistniejących }\end{array}$ & I & C \\
\hline $\begin{array}{l}\text { Nie zaleca się jednoczesnego stosowania dwóch inhibitorów układu } \\
\text { renina-angiotensyna-aldosteron; u chorych na cukrzycę należy unikać } \\
\text { takiego połączenia }\end{array}$ & III & B \\
\hline
\end{tabular}

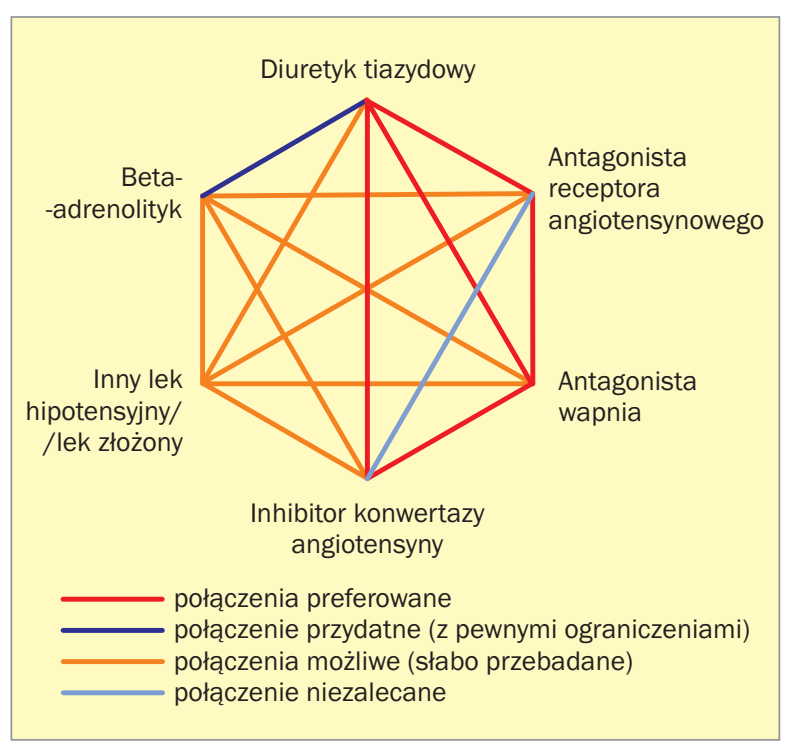

Rycina 2. Zalecane połączenia leków hipotensyjnych według wytycznych European Society of Hypertension/European Society of Cardiology (ESH/ESC) (na podstawie [22])

Obecnie dostępne są liczne preparaty złożone, a większość z nich zawiera lek diuretyczny. Zaleca się wybór leków tiazydopodobnych zamiast diuretyków tiazydowych ze względu na ich korzystniejszy profil metaboliczny [24, 25]. Ponadto w badaniach, takich jak ALLHAT (Antihypertensive and Lipid Lowering Treatment to Prevent Heart Attack Trial) [26], ADVANCE (Action in Diabetes and Vascular Disease) [27], HYVET (HYpertension In The Very Elderly Trial) [28], pot- wierdzono skuteczność leków tiazydopodobnych w prewencji zdarzeń sercowo-naczyniowych. Nie wykazano natomiast wpływu hydrochlorotiazydu na redukcję ryzyka występowania zdarzeń sercowo-naczyniowych w badaniach PHYLLIS [29] oraz MIDAS [30]. Biorąc pod uwagę fakt, że indapamid w przeciwieństwie do diuretyków tiazydowych jest neutralny metabolicznie, jest on zalecanym diuretykiem u chorych z cukrzycą i nadciśnieniem tętniczym [31]. W wytycznych Brytyjskiego Towarzystwa Nadciśnienia Tętniczego (British Society of Hypertension) podkreślono fakt, że diuretyki znacząco różnią się między sobą i zaleca się stosowanie indapamidu lub chlortalidonu, a nie hydrochlorotiazydu [32].

Perindopril jest inhibitorem konwertazy angiotensyny o dobrze udowodnionym działaniu hipotensyjnym. Jego aktywny metabolit charakteryzuje się długim okresem półtrwania (17 h) oraz licznymi właściwościami plejotropowymi. W metaanalizie Savarese'a i wsp. [33] obejmującej 108233 pacjentów (26 badań) wykazano, że inhibitory konwertazy angiotensyny znamiennie obniżały ryzyko wystąpienia pierwszorzędowego punktu końcowego (zgon z przyczyn sercowo-naczyniowych, zawał serca, udar mózgu) o 15\% oraz zmniejszały ryzyko zgonu z każdej przyczyny o 8\%. Wśród inhibitorów konwertazy angiotensyny perindopril był jedynym, który znamiennie zmniejszał częstość występowania pierwszorzędowego punktu końcowego oraz zdarzeń sercowo-naczyniowych (zawał serca i niewydolność serca) [33].

Do badania PICASSO włączono 9257 pacjentów z nadciśnieniem tętniczym nieskutecznie leczonych lekami hipotensyjnymi. Dotychczasową terapię zamieniono na preparat 
złożony zawierający $10 \mathrm{mg}$ perindoprilu i 2,5 mg indapamidu [34]. W badanej grupie u 2762 chorych z nadciśnieniem tętniczym współistniała cukrzyca lub stan przedcukrzycowy. Po 3 miesiącach leczenia uzyskano istotne statystycznie obniżenie średnich wartości ciśnienia tętniczego - w odniesie-

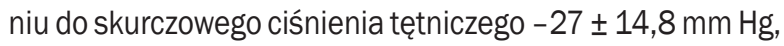
a w przypadku rozkurczowego ciśnienia tętniczego $-12,7 \pm 9,8$ mm Hg. Dobrą kontrolę ciśnienia tętniczego uzyskano u $61 \%$ chorych. W prezentowanym badaniu istotne obniżenie ciśnienia tętniczego odnotowano bez względu na jego wartości wyjściowe: -19,2/-9,4 mm Hg u chorych z nadciśnieniem tętniczym 1. stopnia, -29,2/-13,3 mm Hg u chorych z nadciśnieniem tętniczym 2. stopnia oraz -45,1/-21,5 mm Hg u chorych z nadciśnieniem tętniczym 3. stopnia. Przed włączeniem do badania $73,1 \%$ chorych było leczonych inhibitorem konwertazy angiotensyny lub antagonistą receptora angiotensyny z hydrochlorotiazydem. W tej grupie po 3 miesiącach stosowania perindoprilu i indapamidu wykazano istotną statystycznie redukcję średnich wartości skurczowego ciśnienia tętniczego z 159,5 mm Hg do 132,3 mm Hg oraz rozkurczowego ciśnienia tętniczego z 92,5 mm Hg do 80 mm Hg. Badanie PICASSO dostarczyło danych odnoszących się bezpośrednio do codziennej praktyki lekarskiej i do wyzwań związanych z leczeniem nadciśnienia tętniczego u chorych na cukrzycę. Jego wyniki wskazują, że lek złożony zawierający $10 \mathrm{mg}$ perindoprilu i 2,5 mg indapamidu stanowi skuteczną i dobrze tolerowaną alternatywę dla stosowanego wcześniej, niewystarczająco skutecznego, leczenia hipotensyjnego. U 77 chorych leczonych przed włączeniem do badania inhibitorem konwertazy angiotensyny lub antagonistą receptora angiotensyny z hydrochlorotiazydem po 3 miesiącach stosowania perindoprilu i indapamidu przeprowadzono całodobowe monitorowanie ciśnienia tętniczego. Wykazano istotne statycznie obniżenie średnich wartości skurczowego i rozkurczowego ciśnienia tętniczego w ciągu całej doby [34].

\section{Rokowanie u chorych \\ z nadciśnieniem tętniczym i cukrzycą leczonych perindoprilem i indapamidem}

Jednym z celów badania ADVANCE była ocena wpływu leczenia perindoprilem i indapamidem na częstość występowania incydentów mikro- i makronaczyniowych u chorych na cukrzycę typu 2. Do badania włączono 11140 osób z tą chorobą. Średnie ciśnienie tętnicze w chwili włączenia do badania wynosiło 145/81 mm Hg, a $68 \%$ badanych miało rozpoznane nadciśnienie tętnicze. U 1/3 badanych w wywiadzie wystąpiło powikłanie makroangiopatyczne, a u 1/4 badanych stwierdzono albuminurię. W fazie przed randomizacją pacjenci otrzymywali przez 6 tygodni lek złożony zawierający 2 mg perindoprilu i 0,625 mg indapamidu. Kontynuowano stosowanie wszystkich dotychczas przyjmowanych przez pacjentów leków, poza inhibitorami konwertazy angiotensyny. Po 6 tygodniach stosowania $2 \mathrm{mg}$ perindoprilu i 0,625 mg indapamidu badanych, u których nie obserwowano żadnych objawów nietolerancji, przydzielano losowo do grupy leczonej preparatem złożonym z perindoprilu i indapamidu (2/0,625 mg) lub do grupy przyjmującej placebo. Po 3 miesiącach leczenia dawkę leku zwiększano do $4 \mathrm{mg}$ perindoprilu i 1,25 mg indapamidu. Średni czas obserwacji wynosił 4,3 roku. W porównaniu z pacjentami przydzielonymi do grupy otrzymującej placebo u chorych poddanych terapii lekiem złożonym obserwowano redukcję wartości skurczowego i rozkurczowego ciśnienia tętniczego, odpowiednio, o 5,6 mm Hg i 2,2 $\mathrm{mm} \mathrm{Hg}$. W grupie chorych przyjmujących perindopril z indapamidem stwierdzono znamienne statystycznie zmniejszenie częstości występowania:

- pierwszorzędowego punktu końcowego (łącznie zdarzenia mikro- i makroangiopatyczne) (względna redukcja ryzyka [RRR, relative risk reduction] 9\%; $p=0,041$ );

- zdarzeń wieńcowych łącznie (RRR 14\%; $p=0,020$ );

- zdarzeń nerkowych łącznie (RRR 21\%; p < 0,0001);

- zgonów z przyczyn sercowo-naczyniowych (RRR 18\%; $p=0,027)$;

- śmiertelności całkowitej (RRR 14\%; $p=0,025)$ [28].

U chorych na cukrzyce szczególnie istotne jest zmniejszenie częstości występowania zdarzeń nerkowych. W grupie chorych leczonych perindoprilem i indapamidem, w porównaniu z chorymi otrzymującymi placebo, obserwowano istotne statystycznie ograniczenie rozwoju mikroalbuminurii o 21\%, regresję makroalbuminurii do mikro- lub normoalbuminurii o $16 \%$ oraz redukcję ryzyka nasilenia nefropatii o 24\% [28]. Leczenie perindoprilem i indapamidem było dobrze tolerowane; odsetek chorych przestrzegających zaleceń dotyczących dawkowania wynosił 73\% w grupie badanej i 74\% w grupie przyjmującej placebo.

Znane są wyniki obserwacji prowadzonych po zakończeniu badań w grupie chorych na cukrzycę, w których wykazano długotrwałe, korzystne działanie wcześniejszych interwencji polegających na intensywnej kontroli glikemii, zarówno na punkty końcowe, jak zgony i zdarzenia makronaczyniowe. Nie udowodniono w nich jednak, by intensywne leczenie hipotensyjne, w obserwacji po zakończeniu badania, skutkowało redukcją częstości występowania poważnych zdarzeń $[35,36]$. Obserwacja chorych po zakończeniu badania UKPDS także nie wykazała korzyści klinicznych wynikających z intensywnej terapii hipotensyjnej [37]. Do obserwacji chorych po zakończenie badania ADVANCE zaproszono żyjących uczestników badania, przyjmujących w czasie jego trwania perindopril i indapamid oraz otrzymujących placebo [38]. W badaniu ADVANCE-ON po zakończeniu badania ADVANCE uczestniczyło 8494 chorych (ryc. 3). Mediana czasu trwania obserwacji po zakończeniu badania wynosiła 5,9 roku, a łącznego czasu trwania badania ADVANCE i obserwacji po jego zakończeniu $-9,9$ roku. Wykazana w badaniu ADVANCE średnia różnica 


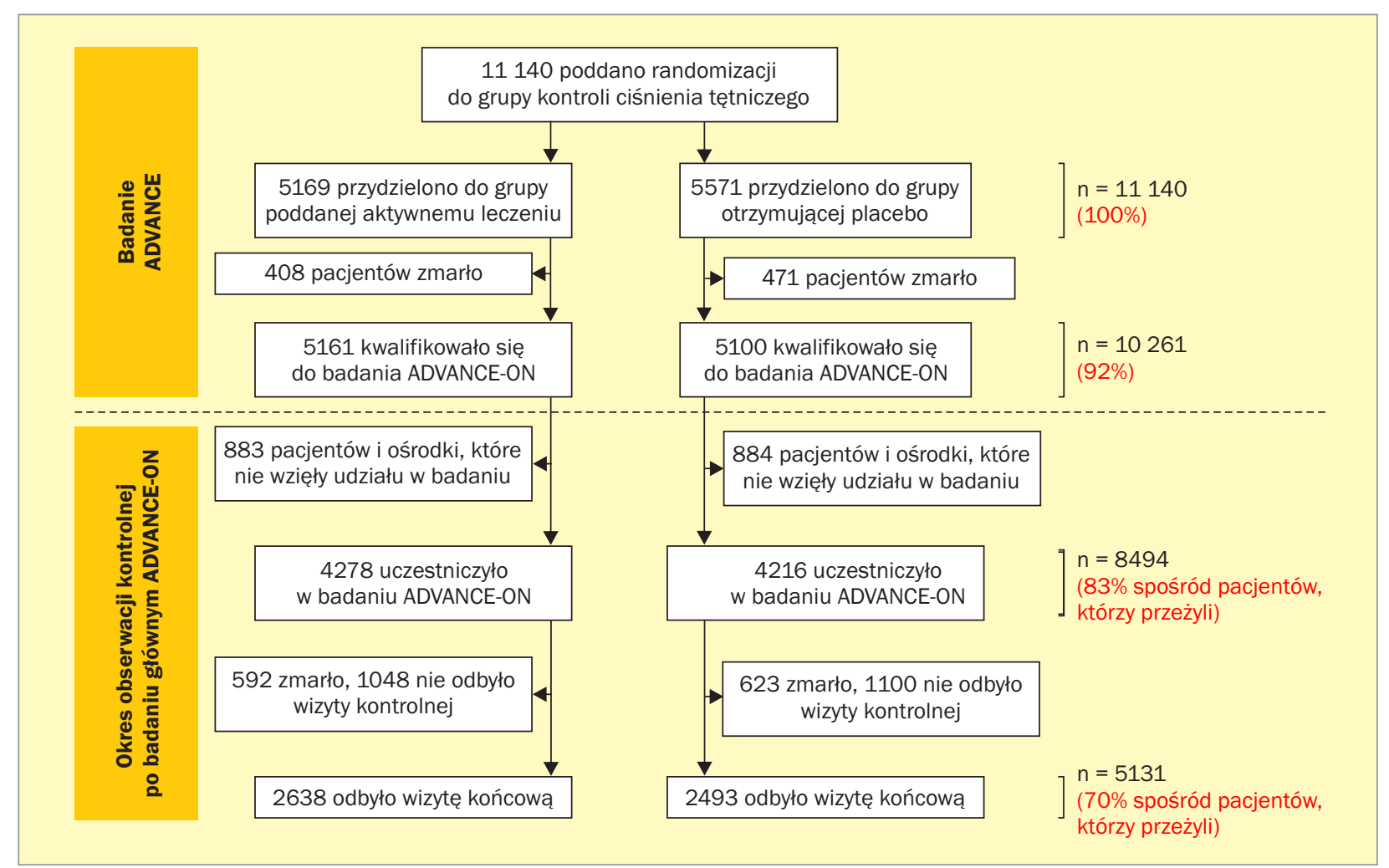

Rycina 3. Plan badania obserwacyjnego ADVANCE-ON (opracowano na podstawie [38])

wartości ciśnienia tętniczego między grupami badaną oraz przyjmującą placebo, wynosząca 5,6/2,2 mm Hg, po 6 miesiącach od zakończenia badania nie była już widoczna. Na koniec okresu obserwacji po zakończeniu badania redukcja ryzyka zgonu z jakiejkolwiek przyczyny i zgonu z przyczyn sercowo-naczyniowych, obserwowana u chorych leczonych w trakcie badania ADVANCE perindoprilem i indapamidem, uległa osłabieniu, ale nadal była istotna statystycznie [38]. Współczynnik ryzyka zgonu z jakiejkolwiek przyczyny wynosił 0,91 ( $p=0,03$ ), a zgonu z przyczyn sercowo-naczyniowych $-0,88(p=0,04)$. Oznacza to, że po 6 latach od zakończenia badania ADVANCE w grupie aktywnie leczonej preparatem złożonym z perindoprilu $\mathrm{z}$ indapamidem $\mathrm{w}$ badaniu ADVANCE obserwowano statystycznie istotne 12-procentowe zmniejszenie śmiertelności z przyczyn sercowo-naczyniowych oraz 9-procentową redukcję liczby zgonów z dowolnej przyczyny (ryc. 4). Zmniejszenie śmiertelności, dotyczące wszystkich badanych podgrup chorych na cukrzyce typu 2 leczonych perindoprilem i indapamidem w preparacie złożonym, wynika zapewne z przeniesienia efektu leczenia z okresu randomizacji. Nie stwierdzono natomiast istotnych statystycznie różnic między grupami leczoną i nieleczoną w badaniu ADVANCE w odniesieniu do drugorzędowych punktów końcowych, tj. poważnych zdarzeń makronaczyniowych, poważnych zdarzeń mikronaczyniowych, zawału serca oraz udaru mózgu.
Stopniowe zmniejszanie się korzyści terapeutycznych w czasie wynika zapewne z zaprzestania kontynuowania terapii preparatem złożonym z perindoprilu z indapamidem po zakończeniu badania ADVANCE i wskazuje na potrzebę utrzymania leczenia stosowanego w okresie badania w celu uzyskania pełnych i długotrwałych efektów terapeutycznych [38]. W badaniu ADVANCE-ON nie wykazano, by w czasie 10-letniej obserwacji chorzy, którzy w okresie ADVANCE byli poddawani intensywnej kontroli glikemii, odnosili korzyści kliniczne w zakresie pierwszorzędowych i drugorzędowych punktów końcowych (zgony ogólne, z przyczyn sercowo-naczyniowych, powikłania makro- i mikronaczyniowe, powikłania oczne). Natomiast intensywna kontrola glikemii za pomocą gliklazydu skutkowała istotną, 46-procentową, redukcją ryzyka rozwoju schyłkowej niewydolności nerek [38]. Analiza danych uzyskanych w trakcie niemal 10-letniej obserwacji chorych na cukrzycę typu 2, obejmującej okres randomizowanego badania i obserwację po jego zakończeniu, wykazała statystycznie znamienną redukcję liczby zgonów z przyczyn sercowo-naczyniowych oraz zgonów z jakiejkolwiek przyczyny, wynikającą z 4,5-letniego wcześniejszego leczenia hipotensyjnego perindoprilem i indapamidem. Rezultat uzyskany w ADVANCE-ON wynikał w największym stopniu z utrzymywania się korzyści z intensywnego leczenia hipotensyjnego stałym połączeniem perindoprilu z indapamidem w badaniu ADVANCE i dowodzi, 


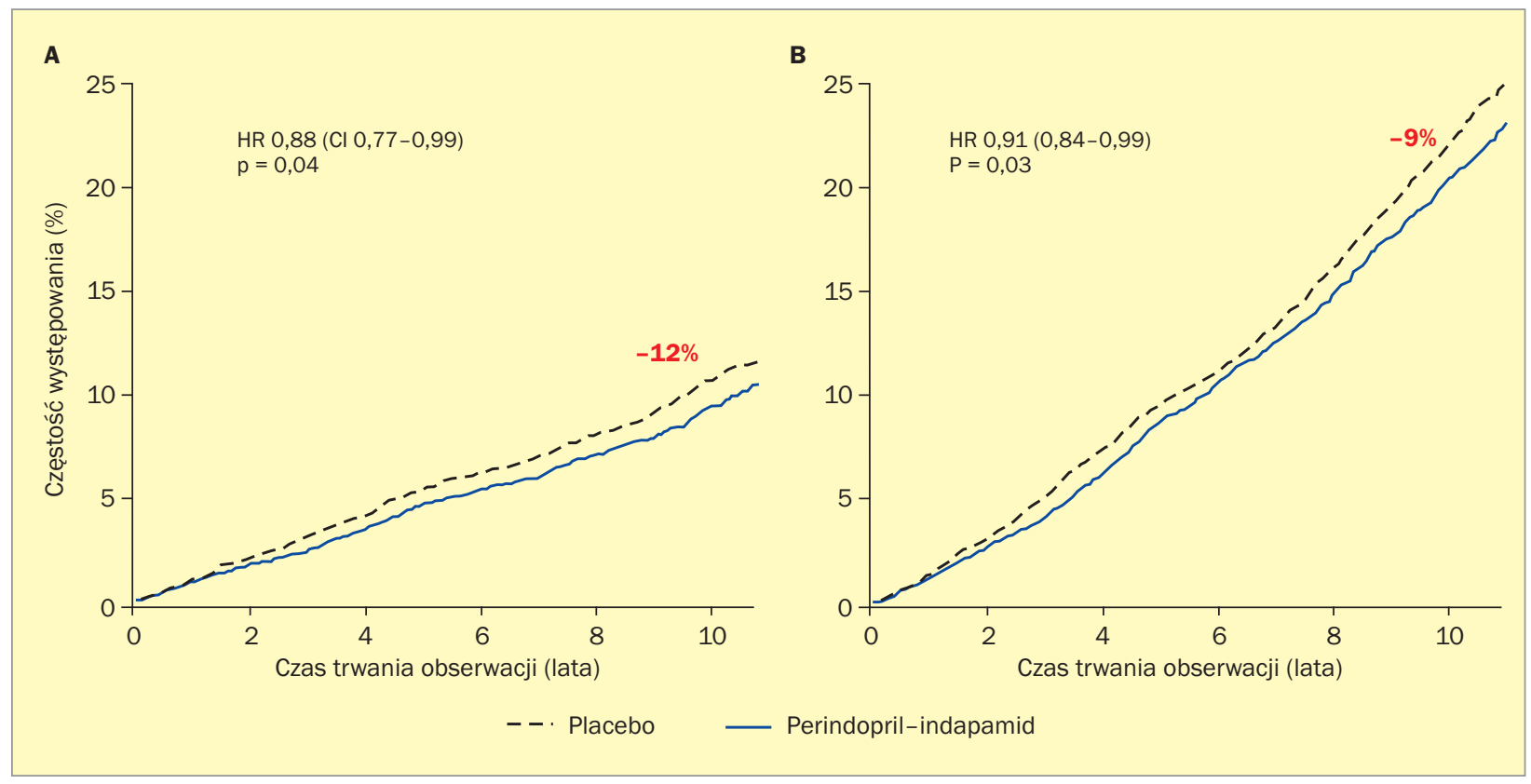

Rycina 4. Częstość występowania zgonów z przyczyn sercowo-naczyniowych (A) oraz z dowolnej przyczyny (B) u chorych w badaniu ADVANCE-ON (opracowano na podstawie [38]); HR (hazard ratio) - współczynnik ryzyka; Cl (confidence interval) - przedział ufności

że wczesne i skuteczne obniżenie ciśnienia tętniczego za pomocą stałego połączenia perindoprilu z indapamidem przekłada się na długotrwałe korzyści kliniczne.

\section{Podsumowanie}

Leczenie złożone perindoprilem i indapamidem jest jednym z najlepiej udokumentowanych połączeń lekowych stosowanych w terapii hipotensyjnej. Badania ADVANCE i ADVANCE-ON ugruntowały rolę perindoprilu i indapamidu w leczeniu nadciśnienia tętniczego u chorych na cukrzycę, wykazując unikatowe, długotrwałe działanie tych leków, prowadzące do redukcji liczby zgonów z przyczyn sercowo-naczyniowych oraz zgonów z jakiejkolwiek przyczyny, utrzymujące się nawet 5 lat po zaprzestaniu leczenia. Zatem leczenie złożone perindoprilem i indapamidem jest zalecane u chorych z nadciśnieniem tętniczym i cukrzycą ze względu na osiąganie docelowych wartości ciśnienia tętniczego, korzystny profil metaboliczny wymienionych leków, zmniejszenie częstości występowania zdarzeń sercowo-naczyniowych oraz redukcję śmiertelności, co podkreślają autorzy opublikowanych w 2015 roku amerykańskich wytycznych dotyczących leczenia cukrzycy [39].

\section{Konflikt interesów}

Autorki deklarują brak konfliktu interesów.

\section{Abstract}

Recent epidemiological data emphasize the ongoing difficulties associated with reducing blood pressure in diabetic hypertensive patients. For hypertensive patients with diabetes mellitus recent guidelines of European Society of Hypertension and European Society of Cardiology recommend considering combination therapy, preferably fixed-dose combinations. Treatments should include renin-angiotensin-aldosterone system inhibitors to prevent from the diabetic nephropathy occurrence. The combination of perindopril with thiazide-like diuretic - indapamide is one of the widely tested in multicentre clinical trials.

Key words: combination therapy, perindopril, indapamide 


\section{Piśmiennictwo}

1. Kearney P.M., Whelton M., Reynolds K. i wsp. Global burden of hypertension: analysis of worldwide data. Lancet 2005; 365: 217-223.

2. Bandosz P., O'Flaherty M., Drygas W. i wsp. Decline in mortality from coronary heart disease in Poland after socioeconomic transformation: modelling study. BMJ 2012; 344: d8136. doi: 10.1136/bmj.d8136.

3. Zdrojewski T., Bandosz P., Szpakowski P. i wsp. Ocena wybranych problemów dotyczących rozpowszechnienia i terapii nadciśnienia tętniczego w Polsce na podstawie badania NATPOL-PLUS. W: Postępy w nefrologii i nadciśnieniu tętniczym. Tom II. Medycyna Praktyczna, Kraków 2002: 11-15.

4. www.natpol. pl. Dostępne na: www.http://gumed.edu.pl/16091.html. Dostęp: 17.10.2011.

5. Ong K.L., Cheung B.M., Man Y.B. i wsp. Prevalence, awareness, treatment and control of hypertension among United States adults 1999-2004. Hypertension 2007; 49: 69-75.

6. Lloyd-Jones D.M., Evans J.C., Larson M.G. i wsp. Differential control of systolic and diastolic blood pressure: factors associated with lack of blood pressure control in the community. Hypertension 2000; 36: 594-599.

7. Bramlage P., Böhm M., Volpe M. i wsp. A global perspective on blood pressure treatment and control in a referred cohort of hypertensive patients. J. Clin. Hypertens. 2010; 12: 666-677.

8. Stephenson J. Noncompliance may cause half of antihypertensive drug "failures". JAMA 1999; 282: 313-314.

9. Gupta A.K., Arshad S., Poulter N.R. Compliance, safety, and effectiveness of fixed-dose combinations of antihypertensive agents: a meta-analysis. Hypertension 2010; 55: 399-407.

10. Corrao G., Parodi A., Zambon A. i wsp. Reduced discontinuation of antihypertensive treatment by two-drug combination as first step. Evidence from daily life practice. J. Hypertens. 2010; 28: 1584-1590.

11. Wald D.S., Law M., Morris J.K. i wsp. Combination therapy versus monotherapy in reducing blood pressure: meta-analysis on 11,000 participants from 42 trials. Am. J. Med. 2009; 122: 290-300.

12. Egan B.M., Bandyopadhyay D., Shaftman S.R. i wsp. Initial monotherapy and combination therapy and hypertension control the first year. Hypertension 2012; 59: 1124-1131.

13. Stamler J., Vaccaro O., Neaton J.D. i wsp. Diabetes, other risk factors, and 12-yr cardiovascular mortality for men screened in the Multiple Risk Factor Intervention Trial. Diabetes Care 1993; 16: 434-444.

14. Schernthaner G., Ritz E., Phillipp T. i wsp. The significance of 24-hour blood pressure monitoring in patients with diabetes mellitus. Dtsch. Med. Wochenschr. 1999; 124: 393-395.

15. Lin J.E., Palmieri V., Roman N.J. i wsp. The impact of diabetes in left ventricular filling pattern in normotensive and hypertensive adults: the Strong Heart Study. J. Am. Coll. Cardiol. 2001; 37: 1943-1949.

16. Nilsson P.M., Lurbe E., Laurent S. The early life origins of early vascular ageing and arterial stiffness: the EVA syndrome. J. Hypertens. 2008; 26 : 1049-1057.

17. Tight blood pressure control and risk of macrovascular and microvascular complications in type 2 diabetes: UKPDS 38. UK Prospective Diabetes Study Group BMJ 1998; 317: 703-713.

18. Hansson L., Zanchetti A., Carruthers S.G. i wsp. Effects of intensive blood-pressure lowering and low-dose aspirin in patients with hypertension: principal results of the Hypertension Optimal Treatment (HOT) randomised trial. HOT Study Group. Lancet 1998; 351: 1755-1762.

19. Cushman W.C., Evans G.W., Byington R.P. i wsp. Effects of intensive bloodpressure control in type 2 diabetes mellitus. N. Engl. J. Med. 2010; 362: 1575-1585.

20. Rydén L., Grant P.J., Anker S.D. i wsp. ESC Guidelines on diabetes, prediabetes, and cardiovascular diseases developed in collaboration with the EASD: the Task Force on diabetes, pre-diabetes, and cardiovascular diseases of the European Society of Cardiology (ESC) and developed in collaboration with the European Association for the Study of Diabetes (EASD). Eur. Heart J. 2013; 34: 3035-3087.
21. Bangalore S., Kumar S., Lobach I. i wsp. Blood pressure targets in subjects with type 2 diabetes mellitus/impaired fasting glucose: observations from traditional and bayesian random-effects meta-analyses of randomized trials. Circulation 2011; 123: 2799-2810.

22. Mancia G., Fagard R., Narkiewicz K. i wsp. 2013 Practice guidelines for the management of arterial hypertension of the European Society of Hypertension (ESH) and the European Society of Cardiology (ESC): ESH/ESC Task Force for the Management of Arterial Hypertension. J. Hypertens. 2013; 31: 1925-1938.

23. Thoenes M., Neuberger H.R., Volpe M. i wsp. Antihypertensive drug therapy and blood pressure control in men and women: an international perspective. J. Hum. Hypertens. 2010; 24: 336-344.

24. Barrios V., Escobar C. Which thiazide to choose as add-on therapy for hypertension? Integr. Blood Press. Control 2014; 30: 35-47.

25. Roush G.C., Ernst M.E., Kostis J.B. i wsp. Head-to-Head Comparisons of Hydrochlorothiazide With Indapamide and Chlorthalidone: Antihypertensive and Metabolic Effects. Hypertension 2015 Mar 2. pii: HYPERTENSIONAHA.114.05021.

26. Rahman M., Ford C.E., Cutler J.A. i wsp. Long-term renal and cardiovascular outcomes in Antihypertensive and Lipid-Lowering Treatment to Prevent Heart Attack Trial (ALLHAT) participants by baseline estimated GFR. Clin. J. Am. Soc. Nephrol. 2012; 7: 989-1002.

27. Beckett N.S., Peters R., Fletcher A.E. i wsp. Treatment of hypertension in patients 80 years of age or older. N. Engl. J. Med. 2008; 358: 1887-1898.

28. Patel A., MacMahon S., Chalmers J. i wsp. Effects of a fixed combination of perindopril and indapamide on macrovascular and microvascular outcomes in patients with type 2 diabetes mellitus (the ADVANCE trial): a randomised controlled trial. Lancet 2007; 370: 829-840.

29. Zanchetti A., Crepaldi G., Bond M.G. i wsp. Different effects of antihypertensive regimens based on fosinopril or hydrochlorothiazide with or without lipid lowering by pravastatin on progression of asymptomatic carotid atherosclerosis: principal results of PHYLLIS - a randomized double-blind trial. Stroke 2004; 35: 2807-2812.

30. Borhani N.O., Brugger S.B., Byington R.P. Multicenter study with isradipine and diuretics against atherosclerosis. US MIDAS Research Group. J. Cardiovasc. Pharmacol. 1990; 15 (supl. 1): S23-S29.

31. Waeber B., Rotaru C., Feihl F. Position of indapamide, a diuretic with vasorelaxant activities, in antihypertensive therapy. Expert Opin. Pharmacother. 2012; 13: 1515-1526.

32. National Clinical Guideline Centre. Hypertension. Clinical management of primary hypertension in adults (NICE clinical guideline 127). The Royal College of Physicians, London 2011.

33. Savarese G., Costanzo P., Cleland J.G. i wsp. A meta-analysis reporting effects of angiotensin-converting enzyme inhibitors and angiotensin receptor blockers in patients without heart failure. J. Am. Coll. Cardiol. 2013; 61: 131-142

34. Farsang C. Efficacy and tolerability of fixed-dose combination of perindopril/indapamide in type 2 diabetes mellitus: PICASSO Trial. Adv. Ther. 2014; 31: 333-344.

35. Nathan D.M., Cleary P.A., Backlund J.Y. i wsp. Intensive diabetes treatment and cardiovascular disease in patients with type 1 diabetes. N. Engl. J. Med. 2005; 353: 2643-2653.

36. Holman R.R., Paul S.K., Bethel M.A. i wsp. 10-year follow-up of intensive glucose control in type 2 diabetes. N. Engl. J. Med. 2008; 359: 1577-1589.

37. Holman R.R., Paul S.K., Bethel M.A. i wsp. Long-term follow-up after tight control of blood pressure in type 2 diabetes. N. Engl. J. Med. 2008; 359 : 1565-1576.

38. Zoungas S., Chalmers J., Neal B. i wsp. Follow-up of blood-pressure lowering and glucose control in type 2 diabetes. N. Engl. J. Med. 2014; 371: 1392-1406.

39. Standards of medical care in diabetes -2015 : summary of revisions. Diabetes Care 2015; 38 (supl. 1): S4. doi: 10.2337/dc15-S003. 